\title{
The Impact of Livestock Grazing on Soil Characteristics in Mount Kilimanjaro, Tanzania
}

\author{
Cosmas Mligo \\ Department of Botany, University of Dar es Salaam, Dar es Salaam, Tanzania \\ Email:mligo@yahoo.co.uk,mligo@udsm.ac.tz
}

Received 24 September 2015; accepted 24 November 2015; published 27 November 2015

Copyright (c) 2015 by author and Scientific Research Publishing Inc.

This work is licensed under the Creative Commons Attribution International License (CC BY). http://creativecommons.org/licenses/by/4.0/

(c) (i) Open Access

\begin{abstract}
Livestock grazing is an anthropogenic disturbance on the soil properties in montane forests of the northern slopes of Mount Kilimanjaro. It was determined the effect of livestock grazing on SOC, N, CEC, SAS, SFD and P in the montane forest. Forty plots were randomly established for collection of soil samples. Data showed livestock grazing decreased the accumulation of SOC and consequently negatively affected the natural pattern of N, P, SFD, CEC and SAS. An opposing pattern of available soil phosphorus was interpreted that the nutrient pool retained in plant tissues particularly in the long-lived trees, which were absent in heavily grazed area. The observed positive correlation between SOC with TN and CEC implies the livestock grazing impacts on the former negatively affected the later soil parameters. Low fungal density in degraded parts of the montane forest indicates that they are sensitive to the current land use change. Based on the observation from this study, it can be regarded that excessive livestock grazing has a long-term negative ramification for soil conservation in montane forest. An important decision has to be sought off with regard to the conservation management of soil characteristics of the montane forest in Kilimanjaro Mountain.
\end{abstract}

\section{Keywords}

Livestock Grazing, Montane Forest, Northern Slopes, Kilimanjaro, Soil

\section{Introduction}

Mount Kilimanjaro is among biodiversity conservation sanctuaries in Tanzania and has recently being promoted to a national park. The mountain is internationally recognized for its richness in biological diversity with over 
900 plant species in the montane forest belt and 2500 species for the whole mountain [1]. The mountain has a complex biodiversity composition and distribution due to multiple bioclimatic belts at different altitudes [2] These belts can be distinguished along the slopes of Mount Kilimanjaro and the montane forest belt covers the major part of the mountain. Despite of the biological complexity of Mount Kilimanjaro, it has been encroached by livestock grazing particularly on the northern slopes of the montane forest. The use of natural habitat for livestock production has caused serious degradation of ecosystems worldwide [3]. This is because of the human population pressure associated with increased in the land-use changes that affect soil properties [4]. The recent land use change from pasture to cropland in Longido District has caused scarcity of pasture and consequently increased the encroachment in montane forests through livestock grazing [5]. The negative impacts of livestock grazing on soil properties in montane forest of Mount Kilimanjaro forms part among recent ecological studies ([5] [6]). Livestock grazing disturbance may be reflected through its impacts on every aspect of soil structure, nutrient cycles and soil microbial communities [7]. Disturbance on surface soils through livestock grazing can influence terrestrial ecosystem fertility by changing the vegetation cover, soil microbial communities, soil organic carbon, nitrogen $(\mathrm{N})$ fixation and phosphorus storage and this may have happened in the montane forest.

The chemical composition of soil organic matter is important for $\mathrm{C}$ and $\mathrm{N}$ cycling and often has been regarded as the limiting factor to primary productivity of an ecosystem [8]. The distribution of the aforementioned nutrient can be altered through livestock grazing in an ecosystem [9] and this may affected their allocation patterns, storage and dynamics [10]. The livestock grazing may affect SOC through changes in plant communities and composition of soil organic matter (SOM) [8]. Vegetation is the source of organic matter that provides with an adsorptive capacity for soil nutrients in forms available for uptake by plants [11] and therefore determines the cation exchange capacity (CEC). As the livestock graze and tramples the soil around the pasture they impair the organization of soil minerals and organic particle aggregates [12] and this may affect soil aggregate stability. Since soil aggregate stability being a major factor determining the level of soil degradation [13], the increased livestock grazing impacts has a negative consequence to the quality of habitat and soils of the montane forest. Soil aggregate stability (SAS) is an indicator of the ability of the soil to accumulate SOC and loss of soil particles through erosion [14] [15]. The SAS is the result of organization of minerals and SOC [12] with a maintained force between particles and this depends on natural habitat conservation management. The encroachment through livestock grazing may contribute to the declines in organic carbon content and aggregate stability [16]. Soil organic carbon (SOC) can be modified by the impact of land use changes [17]. However, the negative impacts of livestock grazing on soils may not be exceptional in the montane forest in Mount Kilimanjaro that has been encroached through livestock grazing over the years because of changes in land-use from conserved montane forest to a pasture. An important management issue is about the impacts of livestock grazing on the amount of SOC, N, P storage in the soil at the moment in which the montane forest is used as pasture land with consistently encroachment in the upper montane within Mount Kilimanjaro. The objective of this study is to assess the impacts of livestock grazing pressure on soil organic carbon, total nitrogen, available soil phosphorus, cation exchange capacity, soil aggregate stability and soil fungal density in montane forest of the northern slopes of Mount Kilimanjaro that has been exposed to a combination of livestock grazing species for effective biodiversity conservation of Kilimanjaro National Park.

\section{Material and Methods}

\subsection{Location and Characteristics of the Study Area}

Mount Kilimanjaro is located in the Northern Tanzania adjacent to Tanzania-Kenya international boundary (Figure 1). The mountain is found between Latitudes $2^{\circ} 45^{\prime} \mathrm{S}$ and $3^{\circ} 25^{\prime} \mathrm{S}$ and between longitudes $37^{\circ} 00^{\prime} \mathrm{E}$ and $37^{\circ} 43^{\prime} \mathrm{E}$ about $300 \mathrm{Km}$ south of equator [2]. Kilimanjaro is the highest mountain in Africa with three discrete peaks, Kibo (5895 m a.s.l.), Mawenzi (5149 m) and Shira (3962 m) [18]. The mountain has a complex biodiversity composition and distribution due to occurrence of many biomes in a single mountain that can be distinguished along its slopes. These include savanna at the lowest altitude (700 - 1000 m.a.s.l.), narrow vegetation of transitional belt (1000 - $1500 \mathrm{~m}$ a.s.l), montane forests (1500 - 2800 m.a.s.l) and alpine belt (2800 - 3500 m.a.s.l) (Figure 1). The montane forest belt covers large part of the mountain and is characterized by a high plant diversity, distributed along an extensive altitudinal range between $1600 \mathrm{~m}$ and $2800 \mathrm{~m}$.a.s.l [2]. The climate of Mt. Kilimanjaro varies from one biome to the other based on altitude gradients and aspect where the montane forest is experiences a typical equatorial climate. The rainfall also varies with exposure to the wind blowing from the 


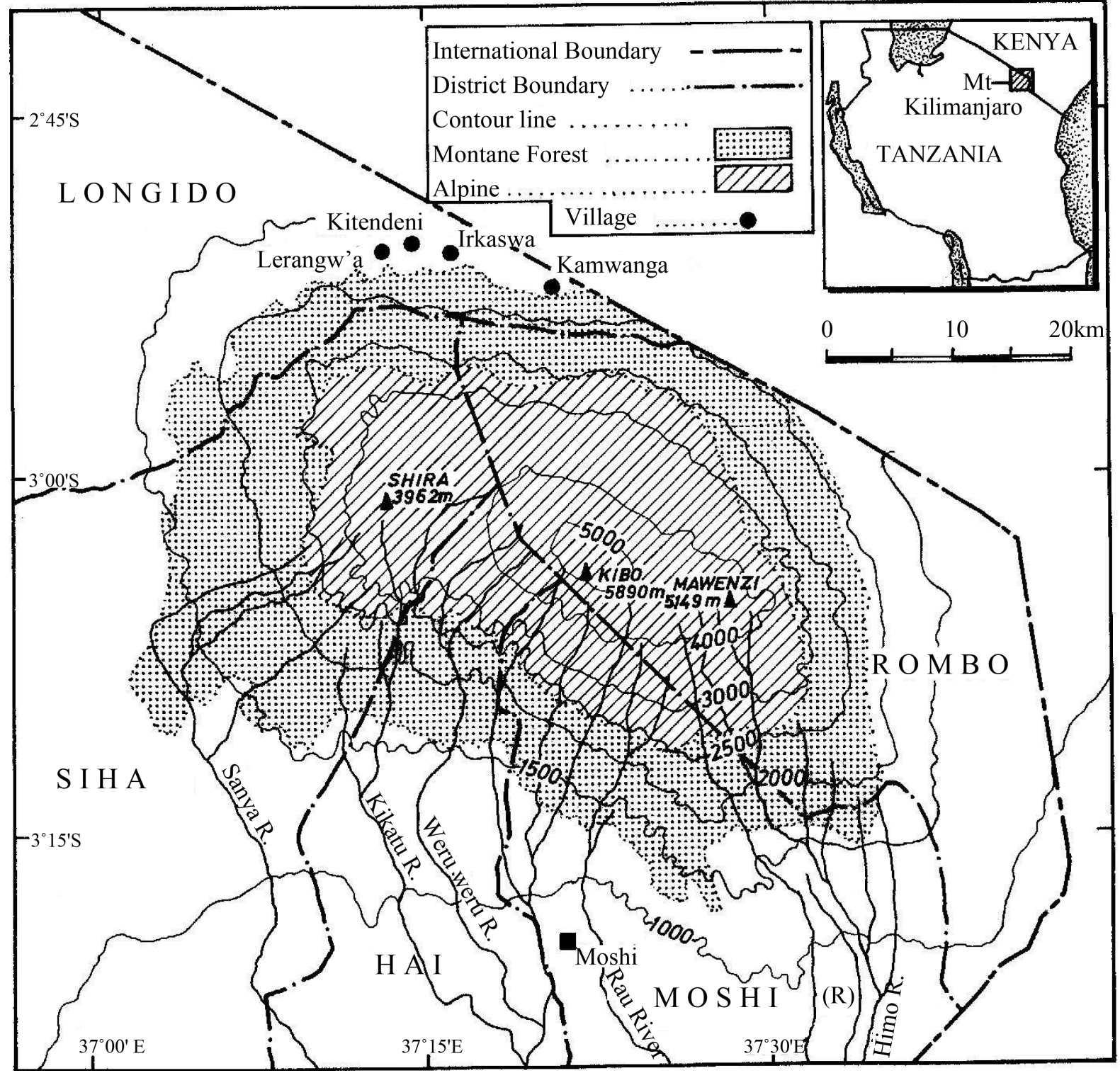

Figure 1. A map showing an altitudinal zone of montane forest in Mount Kilimanjaro.

Indian Ocean where the northern slopes on the shadow sides receive much less rainfall [19]. The montane forest experiences two distinct rainy seasons where the long rainy period occurs between March and May and the short rain periods occurs between November and December and hence the rainfall pattern being bimodal [5]. The maximum mean annual rainfall reaches up to $3000 \mathrm{~mm}$ at $2100 \mathrm{~m}$.a.s.l. on the central southern slopes at the lower part of the montane forest belt and this exceeds an average precipitation received in African high mountains [1], which gradually decreases to less than $500 \mathrm{~mm}$ above $4000 \mathrm{~m}$ in the alpine zone. The mean annual temperature at the foot of the mountain in Moshi (altitude 813 m.a.s.l.) is $23.4^{\circ} \mathrm{C}$ and gradually decreases to $18^{\circ} \mathrm{C}$ at $1500,9.2^{\circ} \mathrm{C}$ at 3100 m.a.s.l. up to $4.5^{\circ} \mathrm{C}$ at 4000 m.a.s.l. [19]. The Kibo (i.e. at 5800 m.a.s.l) normally reaches up to $-7.1^{\circ} \mathrm{C}$ [20]. However, the alpine belt (3500 to $4000 \mathrm{~m}$.a.s.l) experiences summer during the daytime and winter periods during the night [19]. Moshi, Rombo, Hai and Siha Districts of Kilimanjaro Region surround the mountain on the southern-eastern, southwestern and northwestern slopes respectively. Longido District of Arusha Region borders the montane forest on the northern slopes of Mount Kilimanjaro where the study was carried out particularly at Kamwanga, Irkaswa, Kitendeni and Lerangw'a villages (Figure 1). Pastoralist communities have inhabited the district since 1952 [21] and the expansion of aforementioned villages has 
been associated with montane forest encroachment following the increase in livestock populations.

\subsection{Vegetation Characteristics in Montane Forest of Mount Kilimanjaro}

According to Kikoti (2013) [22], variations in species composition among vegetation communities in livestock grazing affected areas of the montane forest based on the dominant plant species and grazing regimes. The commonly occurring plant species in ungrazed areas are Teclea simplicifolia, Cassipourea malosana, Bersama abyssinica, Prunus africana, Erythrococca bongensis, Clausena anisata, Ficus thonningii, Turraea holstii, Olea europaea subsp. africana, Teclea simplicifolia, Ficus lutea, Cassipourea malosana whereas in the least grazed areas are Olea europaea subsp. africana, Teclea simplicifolia, Clausena anisata, Turraea robusta, Vangueria infausta, Turraea holstii, Erythrococca bongensis, Rinorea ilicifolia, Euclea divinorum and Celtis Africana. The vegetation communities in moderately grazed sites are commonly represented by Turraea robusta, Diospyros abyssinica, Olea europaea subsp. africana, Tarenna graveolens, Croton megalocarpus, Commelina benghalensis, Malacantha alnifolia and Teclea simplicifolia [5]. However, the heavily grazed areas are composed of shrubs viz. Carissa spinarum, Indigofera volkensii, Leucas deflexa, Lantana trifolia, Solanum incanum, Hibiscus micranthus and herbaceous community viz. Senecio abyssinicus, Conyza pyrrhopappa, Ruellia tuberosa, Thunbergia alata with a few grass cover represented by Setaria sphacelata, Hyparrhenia filipendula, Heteropogon contortus and Dichanthium annulatum [5]. Some species are common among study sites while others are restricted in some sites only based on the habitat characteristics influenced by livestock grazing. The variation in sensitivity among plant species to livestock grazing pressure may have contributed to their absence in grazed than in ungrazed areas in the montane forest in the northern slopes of mount Kilimanjaro.

\subsection{Soil Sampling Procedures}

The choice of the sampling procedure was based on the observation made during the preliminary survey of which the area was defined based on livestock grazing impacts on soil characteristics, the sampling areas to be covered and the statistical properties for the independent sample representatives of the study area. Based on intensity of livestock grazing, the study area was subdivided into four sampling sites i.e. the overgrazed, moderately grazed, least grazed and ungrazed sites. An area was considered heavily grazed if $>65 \%$ of the quadrat was grazed; moderate if $33 \%-64 \%$ was grazed and the least grazed if $<33 \%$ was grazed as recommended by Warren et al., (1986) [23]. Ten sampling locations were randomly established in each of the four study sites making a total of 40 locations in the entire study area. The soil samples were excavated from three depth classes of $0-5 \mathrm{~cm}, 6-10 \mathrm{~cm}$ and $11-20 \mathrm{~cm}$ in each sampling location. The three depth classes were categorized so as to determine variations in the soil parameters along vertical section of soil horizons. The soil surface layer represented the most impacted with livestock grazing than the subsurface layers, which was expected to be the same in unaffected areas of the montane forest. The variation in soil conditions along the disturbance gradients was predicted based on the floristic composition of the selected site. The excavated soil samples were sealed in plastic bags, labeled and taken to the laboratory of the Botany Department University of Dar es salaam for analyses.

\subsection{Laboratory Analysis of Soil Samples}

The soil samples were air-dried, loosened and sieved through a $2 \mathrm{~mm}$ sieve for determining soil organic carbon, cation exchange capacity, soil aggregate stability, available phosphorus, total nitrogen and soil fungal density. Soil organic carbon (SOC) was determined by using wet oxidation method where $0.5 \mathrm{~g}$ of air dry soil sample was oxidized by $10 \mathrm{ml}$ of potassium dichromate and then titrated against $0.5 \mathrm{~N} \mathrm{FeSO}_{4}$ (Iron (II) sulphate) using Orhto-phenonthroline indicator [24] to get the amount of SOC. The total $\mathrm{N}$ was determined by the Kjeldahl method [25]. The available soil phosphorus was determined by using the ascorbic acid method that involved extracting $\mathrm{P}$ with $0.5 \mathrm{~N} \mathrm{NaHCO}_{3}$ from the soil at $\mathrm{pH} 8.5$ and then determined its concentration through phosphomolybdenum blue method ([11] [26]). The cation exchange capacity (CEC) was determined colorimetrically using ammonium nitrogen $\left(\mathrm{NH}_{4}^{+}-\mathrm{N}\right)$ [11] where $10 \mathrm{~g}$ of the soil sample was leached with 30 mil of $6 \% \mathrm{KCl}$ solution and then treated with ammonium nitrogen to exchange with metal ions on the surface soil colloids. The soil aggregate stability was determined using the flat sieve method as described by Singh and Khera, (2009) [27]. The soil fungal density was determined using spread plate count methods where $10 \mathrm{~g}$ of soil sample was sus- 
pended in $90 \mathrm{ml} \mathrm{Na}_{4} \mathrm{P}_{2} \mathrm{O}_{7} \cdot 10 \mathrm{H}_{2} \mathrm{O}$ to disperse soil organic colloids. It was further diluted with $\mathrm{NaCl}(0.9 \%)$ at the ratio of 1:20,000 and then plated ( $1 \mathrm{ml}$ per plate) on 10 replicates of $5 \%$ potato-dextrose agar (PDA). The plates were incubated at $40^{\circ} \mathrm{C}$ and then isolated for fungi from each replicates in each PDA sample. The number of colony forming units per gram of dry weight (CFU/g of dwt) was obtained for the total mycoflora.

\subsection{Data Analysis}

Repeated measures analysis of variance (ANOVA) was used to compare soil parameters particularly the soil organic carbon, cation exchange capacity, soil aggregate stability, soil fungal density, total nitrogen and soil available phosphorus among grazing regimes (ungrazed, least, moderate and heavily grazed) [28]. The significant difference was assessed at 5\% critical limit and the least significant differences (LSD) among means were assed based on Steel and Torrie, (1980) [29].

\section{Results}

\subsection{The Soil Organic Carbon (SOC), Available Soil Phosphorus (P) and Total Soil Nitrogen (N)}

It was found SOC in a range between $17.32 \%$ and $12.24 \%$ and the pattern decreased with increased livestock grazing pressure among sampling sites within the Montane forest of the northern slopes of Mount Kilimanjaro (Table 1). A significantly higher percentage soil organic carbon was observed in soil samples from ungrazed areas than those from the least grazed areas (Lsd $=5.41, q=5.22, p<0.01$ ), but no significant difference was observed between soils from ungrazed area to those from moderate and heavily grazed areas ( $p>0.05)$. The SOC decreased significantly with increasing in soil depth regardless of little variation in each layer among grazing regimes with no any reflection of the impacts of livestock grazing pressure. The available soil phosphorus $\mathrm{P}$ was in a range between $0.129 \%$ and $0.329 \%$ with the highest in heavily grazed areas with consistent decreasing against livestock distruabnce gradient. Except for the soil samples from the moderately grazed area, the available soil phosphorus was significantly lower in soils from ungrazed sites than those from least grazed area (Lsd = $0.07, \mathrm{q}=5.18, \mathrm{p}<0.01)$ and heavily grazed sites ( $\mathrm{Lsd}=0.174, \mathrm{q}=12.35, \mathrm{p}=0.001)$. Although soils from the least grazed area had significantly higher phosphorus than those in moderately grazed sites (Lsd $=0.055, q=3.9$, $\mathrm{p}<0.05$ ); it had significantly lower than the same in soil samples from the heavily grazed parts ( $\mathrm{Lsd}=0.101, \mathrm{q}=$ 7.17, $\mathrm{p}<0.001)$ (Table 1). The uppermost soil layer (0 - $5 \mathrm{~cm}$ depth) recorded the lowest percentage available P. The soil sample from heavily grazed areas had the highest concentration of soil P than all other soil horizons from ungrazed, least and moderately grazed sites. While significant difference existed among soil depth classes in the soil sample from ungrazed $(\mathrm{F}=22.20, \mathrm{df}=29, \mathrm{p}=0.0001)$ and heavily grazed sites $(\mathrm{F}=4.25, \mathrm{df}=29, \mathrm{p}=$ $0.024)$, there was no significant different among soil layers in least and moderately grazed sites $(\mathrm{p}>0.05)$ (Table 2). The amount of total soil nitrogen ranged between $0.63 \% \pm 0.07 \%$ and $0.96 \% \pm 0.04 \%$, with a significant

Table 1. The amount of soil organic carbon (SOC), nitrogen (N), phosphorus (P), cation exchange capacity (CEC), soil fungal density (SFD and soil aggregate stability (SAS), among grazing regimes in montane forest of Mount Kilimanjaro. Different letters (a, b, c \& and d) means significant difference, $\mathrm{df}=$ degree of freedom, ANOVA-analysis of variance, $\mathrm{F}=$ variance ratio/F-statistic. (The significance difference was assessed at $5 \%$ critical level).

\begin{tabular}{|c|c|c|c|c|c|}
\hline Soil parameter & Ungrazed area & Least grazed area & Moderately grazed area & $\begin{array}{c}\text { Heavily grazed } \\
\text { area }\end{array}$ & ANOVA \\
\hline Organic carbon (\%) & $16.71 \pm 0.609^{a}$ & $11.30 \pm 1.28^{\mathrm{b}}$ & $13.69 \pm 0.95^{\mathrm{b}}$ & $13.52 \pm 1.28^{\mathrm{b}}$ & $\begin{array}{c}F=7.12, \mathrm{df}=39, \\
P=0.0011\end{array}$ \\
\hline Phosphorus (\%) & $0.15 \pm 0.02^{\mathrm{a}}$ & $0.22 \pm 0.015^{\mathrm{b}}$ & $0.16 \pm 0.04^{\mathrm{b}}$ & $0.32 \pm 0.01^{\mathrm{c}}$ & $\begin{array}{c}\mathrm{F}=30.88, \mathrm{df}=39, \\
\mathrm{P}<0.0001\end{array}$ \\
\hline Nitrogen (\%) & $0.96 \pm 0.04^{\mathrm{a}}$ & $0.63 \pm 0.07^{\mathrm{b}}$ & $0.72 \pm 0.051^{\mathrm{b}}$ & $0.71 \pm 0.06^{\mathrm{b}}$ & $\begin{array}{c}F=7.12, \mathrm{df}=39, \\
F=0.0011\end{array}$ \\
\hline CEC (meq/100g) & $121.22 \pm 4.28^{a}$ & $97.05 \pm 4.78^{\mathrm{b}}$ & $96.74 \pm 5.28^{b}$ & $88.45 \pm 3.81^{\mathrm{b}}$ & $\begin{array}{c}F=11.21, d f=39, \\
p=0.0001\end{array}$ \\
\hline SAS (\%) & $76.13 \pm 1.68^{\mathrm{a}}$ & $77.23 \pm 1.96^{\mathrm{a}}$ & $68.19 \pm 2.39^{b}$ & $64.34 \pm 0.76^{\mathrm{b}}$ & $\begin{array}{c}\mathrm{F}=10.78, \mathrm{df}=39, \\
\mathrm{p}<0.0001\end{array}$ \\
\hline $\begin{array}{l}\text { Soil fungal density } \\
\times 10^{5} \text { (cfu/g dwt) }\end{array}$ & $4.86 \pm 0.31^{\mathrm{a}}$ & $3.47 \pm 0.23^{b}$ & $1.54 \pm 0.27^{\mathrm{c}}$ & $0.25 \pm 0.02^{\mathrm{d}}$ & $\begin{array}{c}\mathrm{F}=71.41, \mathrm{df}=39, \\
\mathrm{P}<0.0001\end{array}$ \\
\hline
\end{tabular}


Table 2. The pattern of change in soil organic carbon (SOC), nitrogen (N), available soil phosphorus (P), cation exchange capacity (CEC), soil fungal density (SFD) and soil aggregate stability (SAS), with depth among grazing regimes in Montane forest of Mount Kilimanjaro. Different letters (a, b, c \& and d) means significant difference, df = degree of freedom, $\mathrm{F}=$ variance ratio or F-statistic. (The significance difference was assessed at 5\% critical level).

\begin{tabular}{|c|c|c|c|c|}
\hline $\begin{array}{c}\text { Soil parameters at } \\
\text { various depth classes }\end{array}$ & Ungrazed & Least grazed & Moderate Grazed & Heavily grazed \\
\hline \multirow[t]{4}{*}{ OC (\%) } & $24.36 \pm 1.22^{\mathrm{a}}$ & $15.95 \pm 1.91^{\mathrm{a}}$ & $20.02 \pm 1.81^{\mathrm{a}}$ & $20.12 \pm 1.91^{\mathrm{a}}$ \\
\hline & $16.09 \pm 0.72^{\mathrm{b}}$ & $12.07 \pm 1.25^{\mathrm{a}}$ & $13.62 \pm 0.77^{\mathrm{b}}$ & $13.73 \pm 1.55^{\mathrm{b}}$ \\
\hline & $9.70 \pm 0.64^{c}$ & $5.9 \pm 1.23^{\mathrm{b}}$ & $7.44 \pm 1.03^{\mathrm{c}}$ & $6.7 \pm 0.67^{\mathrm{c}}$ \\
\hline & $\begin{array}{c}\mathrm{F}=66.24, \mathrm{df}=29 \\
\mathrm{p}=0.0001\end{array}$ & $\begin{array}{c}\mathrm{F}=11.44, \mathrm{df}=29 \\
\mathrm{p}=0.0003\end{array}$ & $\begin{array}{c}\mathrm{F}=23.82, \mathrm{df}=29 \\
\mathrm{P}=0.0001\end{array}$ & $\begin{array}{c}\mathrm{F}=20.67, \mathrm{df}=29, \\
\mathrm{P}=0.0001\end{array}$ \\
\hline \multirow[t]{4}{*}{ N (\%) } & $1.38 \pm 0.07^{\mathrm{a}}$ & $0.86 \pm 0.11^{\mathrm{a}}$ & $0.92 \pm 0.12^{\mathrm{a}}$ & $1.06 \pm 0.07^{\mathrm{a}}$ \\
\hline & $0.94 \pm 0.05^{\mathrm{b}}$ & $0.69 \pm 0.06^{\mathrm{a}}$ & $0.83 \pm 0.05^{\mathrm{b}}$ & $0.76 \pm 0.07^{\mathrm{b}}$ \\
\hline & $0.57 \pm 0.042^{c}$ & $0.34 \pm 0.07^{\mathrm{b}}$ & $0.39 \pm 0.05^{\mathrm{c}}$ & $0.33 \pm 0.05^{c}$ \\
\hline & $\begin{array}{c}\mathrm{F}=49.42, \mathrm{df}=29 \\
\mathrm{p}=0.0001\end{array}$ & $\begin{array}{c}F=9.45, \mathrm{df}=29 \\
\mathrm{p}=0.0008\end{array}$ & $\begin{array}{c}\mathrm{F}=12.36, \mathrm{df}=29 \\
\mathrm{p}=0.0002\end{array}$ & $\begin{array}{c}\mathrm{F}=1.6, \mathrm{df}=29, \\
\mathrm{p}=0.21\end{array}$ \\
\hline \multirow[t]{4}{*}{$\mathrm{P}(\%)$} & $0.05 \pm 0.01^{\mathrm{a}}$ & $0.19 \pm 0.01$ & $0.18 \pm 0.02$ & $0.29 \pm 0.01^{\mathrm{a}}$ \\
\hline & $0.11 \pm 0.02^{\mathrm{a}}$ & $0.21 \pm 0.01$ & $0.16 \pm 0.01$ & $0.32 \pm 0.01^{\mathrm{ab}}$ \\
\hline & $0.278 \pm 0.03^{\mathrm{b}}$ & $0.251 \pm 0.03$ & $0.150 \pm 0.01$ & $0.34 \pm 0.006^{\mathrm{b}}$ \\
\hline & $\begin{array}{c}\mathrm{F}=22.20, \mathrm{df}=29 \\
\mathrm{p}=0.0001\end{array}$ & $\begin{array}{c}\mathrm{F}=2.01, \mathrm{df}=29 \\
\mathrm{p}=0.153\end{array}$ & $\begin{array}{c}\mathrm{F}=1.65, \mathrm{df}=29 \\
\mathrm{p}=0.21\end{array}$ & $\begin{array}{c}\mathrm{F}=4.26, \mathrm{df}=29, \\
\mathrm{p}=0.0247\end{array}$ \\
\hline \multicolumn{5}{|l|}{ CEC (meq./100g) } \\
\hline $0-5$ & $146.01 \pm 4.76^{\mathrm{a}}$ & $114.28 \pm 7.49^{\mathrm{a}}$ & $110.93 \pm 6.95$ & $98.59 \pm 4.24^{\mathrm{ab}}$ \\
\hline $5-10$ & $122.65 \pm 2.79^{\mathrm{ab}}$ & $101.31 \pm 5.22^{\mathrm{ab}}$ & $99.53 \pm 5.59^{\mathrm{ab}}$ & $91.48 \pm 4.28^{\mathrm{b}}$ \\
\hline $10-20$ & $95.01 \pm 11.55^{\mathrm{b}}$ & $75.58 \pm 5.55^{\mathrm{c}}$ & $79.75 \pm 4.01^{\mathrm{b}}$ & $75.28 \pm 4.28^{\mathrm{c}}$ \\
\hline & $\begin{array}{c}F=11.93, f=29 \\
p=0.0002\end{array}$ & $\begin{array}{c}\mathrm{F}=12.23, \mathrm{df}=29 \\
\mathrm{p}=0.0005\end{array}$ & $\begin{array}{c}\mathrm{F}=7.82, \mathrm{df}=29 \\
\mathrm{p}=0.0021\end{array}$ & $\begin{array}{c}\mathrm{F}=7.84, \mathrm{df}=29, \\
\mathrm{p}=0.0021\end{array}$ \\
\hline \multicolumn{5}{|c|}{$\mathrm{SFD} \times 10^{5}(\mathrm{cfu} / \mathrm{g} \mathrm{dwt})$} \\
\hline \multirow[t]{4}{*}{$0-5$} & $7.67 \pm 0.39^{\mathrm{a}}$ & $5.75 \pm 0.21^{\mathrm{a}}$ & $2.6 \pm 0.40^{\mathrm{a}}$ & $0.48 \pm 0.19$ \\
\hline & $4.77 \pm 0.44^{\mathrm{b}}$ & $2.97 \pm 0.31^{b}$ & $1.6 \pm 0.37^{\mathrm{b}}$ & $0.28 \pm 0.07$ \\
\hline & $2.15 \pm 0.35^{\mathrm{c}}$ & $1.7 \pm 0.31^{\mathrm{c}}$ & $1.03 \pm 0.23^{\mathrm{b}}$ & $0.27 \pm 0.05$ \\
\hline & $\begin{array}{c}\mathrm{F}=46.86, \mathrm{df}=29 \\
\mathrm{p}=0.0001\end{array}$ & $\begin{array}{c}\mathrm{F}=46.36, \mathrm{df}=29 \\
\mathrm{P}=0.0001\end{array}$ & $\begin{array}{c}\mathrm{F}=5.29, \mathrm{df}=29 \\
\quad \mathrm{p}=0.0115\end{array}$ & $\begin{array}{c}\mathrm{F}=0.88, \mathrm{df}=29, \\
\mathrm{p}=0.423\end{array}$ \\
\hline \multirow[t]{4}{*}{ SAS (\%) } & $80.53 \pm 2.37$ & $75.75 \pm 2.118^{\mathrm{a}}$ & $73.31 \pm 2.11$ & $62.87 \pm 1.09$ \\
\hline & $73.78 \pm 1.98$ & $72.78 \pm 3.29^{\mathrm{ab}}$ & $67.42 \pm 2.42$ & $66.13 \pm 1.34$ \\
\hline & $74.08 \pm 2.14$ & $83.143 \pm 1.85^{\mathrm{ac}}$ & $63.849 \pm 5.87$ & $64.03 \pm 1.12$ \\
\hline & $\begin{array}{c}\mathrm{F}=3.08, \mathrm{df}=29, \\
\quad P=0.062\end{array}$ & $\begin{array}{c}\mathrm{F}=4.54, \mathrm{df}=29 \\
\mathrm{p}=0.0199\end{array}$ & $\begin{array}{c}\mathrm{F}=1.53, \mathrm{df}=29 \\
\mathrm{p}=0.235\end{array}$ & $\begin{array}{c}\mathrm{F}=1.92, \mathrm{df}=29, \\
\mathrm{p}=0.166\end{array}$ \\
\hline
\end{tabular}

difference among sites affected with livestock grazing regimes $(\mathrm{F}=7.12 \mathrm{df}=39, \mathrm{p}=0.0011)$ (Table 1$)$ and the same was significantly correlated with SOC in all study sites (Table 3) regardless of the prevailing livestock disturbance regime. The post ANOVA test at the least significant difference showed higher concentration of total nitrogen in ungrazed than in the least grazed areas (Lsd $=0.334, \mathrm{q}=6.169, \mathrm{p}<0.001$ ); moderately grazed $($ Lsd $=0.249, \mathrm{q}=4.599, \mathrm{p}<0.05)$; and heavily grazed areas $(\mathrm{Lsd}=0.251, \mathrm{q}=4.63, \mathrm{p}<0.05)$. However, no significant difference in concentration of total soil nitrogen was observed among the remaining pairs of the study sites (Table 1), although a significant decrease in TN with depths was observed in livestock grazing regimes in 
Table 3. The relationship between soil organic carbon (SOC) with nitrogen (N), available soil phosphorus (P), cation exchange capacity (CEC), soil fungal density (SFD) and soil aggregate stability (SAS), in areas with different levels of grazing pressure in Montane forest of Mount Kilimanjaro. The significance of the relationship was assessed at $5 \%$ critical level, $r=$ correlation coefficient, $P$ = probability of the relationship.

\begin{tabular}{cccccc}
\hline Soil parameters & Ungrazed & Least grazed & Moderate grazed & Heavily grazed \\
\hline $\mathrm{N}$ & $r$ & 0.966 & 0.936 & 0.718 & 0.9566 \\
& $p$ & 0.0001 & 0.0001 & 0.0127 & 0.001 \\
$\mathrm{P}$ & $r$ & 0.103 & 0.9293 & -0.3657 & 0.2796 \\
& $p$ & 0.7628 & 0.0109 & 0.2695 & 0.4051 \\
$\mathrm{CEC}$ & $r$ & 0.1434 & 0.8526 & 0.7715 & 0.8155 \\
& $p$ & 0.674 & 0.0009 & 0.0054 & 0.0022 \\
SFD & $r$ & 0.0266 & 0.0701 & 0.273 & 0.507 \\
& $p$ & 0.9168 & 0.8357 & 0.4167 & 0.114 \\
ASA & $r$ & -0.3898 & -0.1541 & -0.2866 & -0.1614 \\
\end{tabular}

the study area.

\subsection{The Soil Cation Exchange Capacity (CEC)}

The cation exchange capacity was an aspect of importance considered in this study about nutrient mobility within the soil colloidal surface such that livestock grazing was regarded to have interfered with natural cationic interplays. The soil CEC ranged between 96 and $125.50 \mathrm{meq} / 100 \mathrm{~g}$ of oven dry soil and varied significantly among sampling sites under different livestock grazing exposure $(\mathrm{F}=11.21 \mathrm{df}=39, \mathrm{p}=0.0001)$ (Table 1$)$. Post ANOVA test showed a significantly higher CEC in the soils from ungrazed sites than those in the least grazed $($ Lsd $=2.4 .16, \mathrm{q}=5.72, \mathrm{p}<0.01)$, moderate $($ Lsd $=24.48, \mathrm{q}=5.79, \mathrm{p}<0.01)$ heavily grazed areas $(\mathrm{Lsd}=32.77$, $q=7.76, p<0.001)$. It was observed no significant difference in CEC values from among the least, moderate and heavily grazed areas $(\mathrm{p}>0.05)$ (Table 1$)$. The uppermost soil layers experienced the highest CEC but significantly decreased with soil depths. Regardless of high CEC values in the upper most soil layer than the deeper horizons, the heavily grazed parts had consistently lowest CEC of all the grazing regimes in the montane forest (Table 2), which was significantly correlated with SOC (Table 3).

\subsection{The Soil Aggregate Stability (SAS) and Soil Fungal Density (SFD)}

The soil aggregates were more stable in soils from least grazed $(77.23 \% \pm 1.96 \%)$ followed by ungrazed $(76.13 \% \pm 1.68 \%)$, moderate grazed and the lowest was observed in heavily grazed sites with the significant differences $(\mathrm{F}=71.41, \mathrm{df}=39, \mathrm{p}=0.001$ ) among sites (Table 1$)$. The post ANOVA test (at the least significant difference) showed an observable significant decline in SAS with increasing grazing pressure i.e. the ungrazed parts had significantly more stable soil particulate aggregation than it was in the least (Lsd $=1.39, \mathrm{q}=5.75, \mathrm{p}<$ 0.01 ), moderate (Lsd $=3.316, \mathrm{q}=13.73, \mathrm{p}<0.001)$ and heavily grazed sites (Lsd $=4.613, \mathrm{q}=19.1, \mathrm{q}<0.001$ ) (Table 1). Also, the SA stability decreased with depth in ungrazed and moderately grazed parts with no clear pattern in soil samples from heavily grazed areas. However, an observable significant decrease in soil aggregates stability with increasing soil depth classes in ungrazed sites. The negatively impacted soil fungal density (SFD) was observed in grazed areas of the montane forest such that soil samples from ungrazed areas recorded the highest density $(4.86 \pm 0.31) \times 10^{5}$ colony forming unit per gram of dry weight $(\mathrm{CFU} / \mathrm{g} \mathrm{dwt})$ and the lowest was observed in soils from heavily grazed sites $(0.25 \pm 0.021) \times 10^{5}$ (CFU/g dwt). Because of the negative impacts of livestock grazing, a significant differences in fungal densities existed among soils between non-impacted and impacted areas at different levels based on repeated measures analysis of variance, $(F=71.42, f=39, p=$ 0.0001). The pattern followed the trend of increasing in grazing pressure and a significantly lowest soil fungal density was observed in soil from heavily grazed sites than in moderate (Lsd $=1.297, q=5.37, p<0.01$ ), least (Lsd = 3.22, $\mathrm{q}=13.34, \mathrm{p}<0.001)$ and ungrazed site (Lsd $=4.61, \mathrm{q}=19.01, \mathrm{p}<0.001)($ Table 1$)$. The pattern of 
SFD significantly decreased with increasing in depth classes in ungrazed, least and moderately grazed, however it was observed no difference among depth classes in heavily grazed sites $(\mathrm{P}>0.05)$ (Table 2).

\section{Discussion}

\subsection{The Effect of Livestock Grazing on Soil Organic Carbon (SOC)}

A number of studies reported on the influence of livestock grazing on the amount of soil organic carbon (SOC) [4]. Observation from this study demonstrated a significantly decreased in SOC with increased grazing pressure in the montane forest of Mount Kilimanjaro. Previously Kikoti and Mligo, (2015) [5] reported on the impact of livestock grazing on plant species composition and diversity including the natural regeneration patterns within the montane forest. These impacts are accompanied with changes in accumulation of soil organic carbon in the montane forest. As the domestic animals graze on fresh forage, they contribute to the reduction in the amount of soil organic carbon accumulating in the montane forest.

A significantly higher SOC was observed in ungrazed area than the least grazed site regardless of the pattern of increasing in grazing pressure. However, the existing little variation in amount of SOC between ungrazed and moderate to heavily grazed sites implies that the impacts on the aforementioned soil parameter may have not reached the level of significance. The soil organic carbon originates from numerous plant species of which their high representation have been favoured by moderate and the least levels of livestock grazing. The more pristine zones in the montane forest had high organic carbon than those in heavily grazed areas. Trampling on litter and herbaceous life forms as the livestock in numbers move around in grazed parts of the montane forest, they also destroyed the vegetation cover and reduced the incorporation of plant residues into the soil organic carbon and this may have affected its dynamics in the soil.

The undisturbed soils contained SOC accumulated far deeper into the soil horizons while those from the heavily grazed sites had its SOC accumulating near the soil surface which makes it vulnerable to losses following high microbial activity. The reduced vegetation cover through grazing causes an increased land surface heating that accelerates organic matter decomposition rate [30] and soil organic carbon loss. However the presence of deep-rooted plants (trees) that gradually decomposing when plant dies in combination with leaf litter decomposition may have contributed to high SOC in ungrazed and least grazed area than in heavily grazed area. A few shrubs, grasses and herbs with shallow roots contribute to annual litter deposition that is also suppressed by herbivores and this resulted into low SOC accumulation. It can be considered that, the observed higher SOC under moderate grazing in the montane forest implies that, there is a room that allows gradual littler decomposition and organic matter buildups and that is why a significantly low of the same was observed in soils exposed to heavy grazing. In contrast, some studies have reported a higher soil C storage in heavily grazed sites ([31][33]), mainly because of increased root production in the surface soil that accompanied with changes in species composition. It is strongly suggested that, excessively livestock grazing is the cause of a significant negative impacts on SOC in the encroached montane forest.

\subsection{Variation in Total Available Soil Phosphorus among Grazing Regimes}

There was an observable significant difference in percentage soil phosphorus among sampling sites in the montane forest of Mount Kilimanjaro and high concentration was recorded in heavily grazed area. Regardless of having high percentage $\mathrm{P}$ in the least than in moderate grazed sites, they both recorded significantly lower $\mathrm{P}$ than it was found in heavily grazed areas. This implies that the nutrients pool remained in the soil in the absence of long-lived plants or large trees. It was expected higher concentration of P in shallow depth $(0-5 \mathrm{~cm})$ than in deeper horizon $(10-20 \mathrm{~cm})$, however a significantly higher concentration was observed at $10-20 \mathrm{~cm}$ depth than other depth classes except in the least and the moderately grazed areas. Mligo, (2008) [34] found a very small concentration of phosphorus in soils of the less affected area and large amount was found in plant materials in heavily grazed areas in the semi-arid Mbulu District. This implies that any small amounts of the available soil phosphorus may always be taken up by the plant species growing in the ungrazed areas. Plant species have the ability to concentrate even a small amount of phosphorus available in the soil [35] leaving soil with poor of the aforementioned elements. The presence of long-lived trees in ungrazed or least grazed sites accumulate large amount of soil P making it low in the soil than in the plant tissues [34] and therefore the P reservoir in most tropical forests. The absence of long-lived plant species because of heavy grazing makes soil phosphorus 
to easily dissolve in soil water and leached in the deeper soil horizons. Based on this controversy in P patterns, it can be considered heavy grazing contribute to inhibition of trees regeneration that could otherwise controls the biogeochemical cycle of $\mathrm{P}$ in the montane forest. As the soil is being trampled with livestock continuously in heavily grazed, it becomes compact and difficult for root penetration and consequently reduced the uptake of phosphorus by plants from the soil. This is the reason why in heavily grazed area; the soil remained with high concentration of available soil phosphorus. However the soils in ungrazed area replenish phosphorus through mineralisation of soil organic matter [36]. The decomposition of organic matter possibly provides favourable effects on phosphorus dynamics of the soil in addition to the mineralisation and release of the element [37].

\subsection{The Effect of Livestock Grazing on the Total Soil Nitrogen}

The impacts of livestock grazing on total soil $\mathrm{N}$ storage have been reported through a number of studies ([4] [38]). The percentage total nitrogen $(\mathrm{N})$ responded negatively with increased livestock grazing gradients such that soils from moderate and heavily grazed areas in the montane forest were significantly lower than in the least and ungrazed areas. Heaney and Proctor (1989) [39] pointed out that nitrogen is the most common limiting nutrient for plant growth because it is needed by plants in large quantity than other nutrient elements. The removal of aboveground biomass by grazing and browsing animals reduces nitrogen inputs into the soil and affected the regeneration and performance of forest dependent plant species in heavily grazed sites. Since nitrogen being an integral component of essential plant compounds [40], its presence in the soil stimulates plant species root development and the uptake of other nutrient elements. Low concentration of soil nitrogen therefore favours negatively the establishment of plant species in heavily grazed sites where a number of plant patches has previously been observed in heavily grazed area of the montane forest [22]. Because of plant species failure to regenerate in the heavily grazed sites [6], it results into low plant species composition and consequently low organic matter deposition in $\mathrm{N}$ deficient soils. In this regard, soil nitrogen remains one among limiting nutrient elements because of its influence on plant species composition [41] and soil organic matter deposition in the study areas.

Because of livestock grazing degrades natural habitat and the plants become disabled to absorb mineralized nitrogen efficiently from the soil, thus a loss of nitrogen through leaching [42]. The high soil total nitrogen in the least and ungrazed sites determined the natural performance of plant species with a concomitant accumulation of organic matter which ensures continuous mineralization of $\mathrm{N}$ in the soils. Nitrogen mineralization is accelerated by an increase turnover rate of biomass [43], which in turns increased the rate of organic matter decomposition [44]. Therefore the increased in total soil nitrogen is contributed by the decomposition of soil organic matter as pointed out by Hatton and Smart (1984) [45].

The soil organic carbon content in least and ungrazed area influences the rate of freeing of nitrogen by the microorganisms since nitrogen is tied up within an organic carbon complex [46]. The soils not impacted with livestock grazing as it was observed in ungrazed sites of the montane forest stored large amount of nitrogen in tissues of a long lived stands where only the excess nitrogen is nitrified and used by plants. The grazing and browsing affected areas composed of low nitrogen concentration because the rate of Nitrogen $(\mathrm{N})$ supply in the soil through mineralization has also been interfered. With an observed significant positive correlation in Table 3 implies an intimate relationship between the soil organic carbon and nitrogen contents in the soil as they are tightly coupled as pointed out by Gol (2009) [47], such that livestock grazing impacts on the former significantly affect the later in the montane forest. Decrease in carbon input due to grazing decrease nitrogen retention within the soil [48]. Soils from ungrazed areas recorded high total nitrogen concentration because the nitrogen mineralization process has not been interfered with livestock grazing. The pristine habitat/ungrazed ensures high turnover rate of biomass that maintain nitrogen mineralization in a course of organic matter decomposition; although the patterns depends on variations in soil moisture contents [49]. The least and ungrazed areas contain plant species with large canopy cover (eg. Teclea simplicifolia, Cassipourea malosana, Prunus africana, Ficus thonningii, Turraea holstii, Teclea simplicifolia and Ficus lutea [5], that preserves moisture favourable for microbial activity and this increase litter decomposition rate that resulted into higher nitrogen than the soils from ungrazed parts. Low $\mathrm{N}$ in heavily grazed area compared with the same in ungrazed area implies that livestock grazing has a negative potential to nitrogen storage in the montane forest habitats. However, my results are contrary to those by Li et al., (2011) [10] that, soils in heavily grazed sites had a better potential for N storage regardless of the differences in the study habitats conditions. It is most probably that, the montane forest habitat is more sensitive to livestock grazing disturbance as reflected in this study. 


\subsection{The Effect of Livestock Grazing on Soil Aggregate Stability}

Shrestha et al., (2007) [50] concluded that different management practices (viz. conservation and pasture) have strong impacts on soil organic carbon dynamics and soil aggregate stability. The soil organic carbon content determines the stability of soil particle aggregates [12]. It was observed a negative effect of livestock grazing on soil aggregate stability in the montane forest of Mount Kilimanjaro (Table 1). The soil particle aggregates were significantly stable in ungrazed than in grazed areas (Table 1). This is because soils in heavily grazed areas are frequently occupied by livestock and face a high level of trampling impacts that significantly lowered the soil aggregate stability than the less impacted areas or sites not occupied by livestock in Montane forest. The frequently translocated livestock in the montane forest defragment soil clods (macro-aggregates) through hooves into fine particles (micro-aggregates), which resulted into low soil aggregate stability in heavily grazed area. The existence of fine particles increases the rate of organic matter decomposition and lowers SOC, as was the case in heavily trampled soils. Since SOC is a SA linking constituent [51], low soil organic carbon accumulation may be the outcome of unstable soil particle aggregates in grazed parts of the montane forest. Because SOC enhances soil particle aggregates [12] it may be the reason for the observed pattern of SAS in the montane forest where heavy grazing resulted to a significantly lower SAS than ungrazed parts. Treading impairs soil aggregates (that protect SOC from excessive microbial activity [52], therefore the reason for low SAS in heavily grazed area. Since soil organic matter provides the basic structure of soil particle aggregates [52], trampling enhances microbial turnover rate and promotes the rate of decomposition and consequently decreased SAS under heavily grazed condition. Regardless of highest SOC turnover rate contributed by annual plants in grazed areas, it lasts shortly because of lack of protection from stable soil particle aggregates.

Because of livestock grazing pressure in montane forest, the particle aggregates have been impaired and has been unable to retain similar amount of SOC as it was in un-impacted sites. Finding from this study have been supported by Hobley et al., (2014) [53] that livestock grazing pressure contribute to poor SOC storage because of an impaired soil aggregation. Because of soil compaction in the uppermost layer in moderate and heavily grazed areas, a significantly lower aggregate stability was observed and this makes the soil surface vulnerable to further degradation. Low SAS may cause rapid desiccation as water surface runoffs do little to infiltrate within soil layers. The soil compaction, low aggregate stability and dry habitats may have prevented the performance of trees in heavily grazed areas in the montane forest. The lowest SAS in heavily grazed sites of the monante forest can be regarded as an ecological degraded habitat, which may not be suitable to support high biodiversity.

\subsection{The Effect of Livestock Grazing on Soil Fungal Density (SFD)}

It was observed significant difference in fungal density in soil from among study sites affected by livestock grazing pressure (Table 1). High fungal density was observed in soil samples from the pristine habitat where no indication of negative livestock impacts (Table 1). Frank et al., (1995) [31] reported that soil microorganisms are important in nutrient biogeochemistry (e.g. decomposition, mineralization, absorption and soil stabilization) and therefore greatly influence the nutrient storage in the soil. The grazing pressure in the montane forest negatively affected the fungal communities where the composition decreased and only in favour of disturbance tolerant species in degraded montane forest habitats. Kageyama et al., 2013 [54] concluded that a response of the microbial community to major disturbances implies a rapid shift to new environment that include the decrease in substrate quality. The changes in substrate availability required for mineralization potentially influence microbial growth and communities [55]. The removal of plant cover through livestock grazing exposed soils to drying and lowered the soil fungal density and this limits soil microbial activities. The fungal density required for decomposing leaf litter on the forest floor and ground surface affects soil organic carbon and nutrient pools. With a prevailing microbial activities performed by small number of fungi in heavily grazed areas, it is anticipated that the fungal communities may be characterized by species that can survive livestock impacts and those that are sensitive to grazing are only available in ungrazed areas of montane forest.

The soil in natural habitats accommodates diverse microbes [56], which in turn are responsible for soil structural resilience. The soil compaction through livestock grazing degrades the quality of microbial habitat and this is the result of low fungal density in heavily grazed parts of the montane forest. Allison and Martiny (2008) [57] pointed out that the composition of microbial communities depends on the ability of individuals to survive and adapt to new conditions following large-scale disturbance. The significantly lowest fungal density in heavily grazed areas implies that only a few fungal communities are able to perform in highly impacted parts than the 
undisturbed areas. Low fungal density is a result of low soil microbial diversity and this implies livestock grazing reduces the composition of microbial community and limit variety soil biotic activity in the soil. The interfered microbial process makes the soil unfavourable for the support of the aboveground vegetation cover and this jeopardizes the biodiversity conservation in montane forest of Kilimanjaro Mountain.

\subsection{The Impacts of Grazing Pressure on Soil Cation Exchange Capacity (CEC)}

Kadeba (1974) [58] pointed out that a significant correlation between soil organic matter and extractable cations exists. It has been reported the highest CEC value by (Mligo, 2004) [59] at the soil depth of $0-5 \mathrm{~cm}$ that decreased with increasing soil horizons (6 - $10 \mathrm{~cm}$ and $11-20 \mathrm{~cm}$ ) in the semi-arid Mbulu District that has been used for livestock grazing since the beginning of $19^{\text {th }}$ century. Similar findings have been observed in montane forest belt in Mount Kilimanjaro which has been affected by livestock grazing. Since the upper horizons contain higher organic matter contents than the deeper horizons, they provide adsorption sites onto which the cations are attached. Heavy grazing in parts of the montane forest removes SOC on the soil surface layers that reduced the binding sites for cations resulting into low CEC in the upper horizons than the least and moderate as well as in the ungrazed areas. Since the pattern of soil CEC followed the intensity of livestock disturbance gradient, it was considered in this study that livestock grazing resulted into low CEC in grazed sites of the montane forest.

\section{Conclusion}

Data from this study allowed establishment of livestock grazing to be the major soil degrading activity in the montane forest based SOC, N, P, SAS, CEC and SFD. Livestock grazing decreased the accumulation of SOC and consequently negatively affected the natural pattern of N, P, SFD, CEC and SAS. An opposing trend of the pattern of impacts on available soil phosphorus was interpreted that the nutrients pool retained in plant tissues particularly in the long lived trees, whereas high $\mathrm{P}$ in soil of the heavily grazed area implies the absence of long lived trees and the soil remains as P reservoir. However, it is hard to establish the impact of livestock grazing on the vertical distribution of the determined parameters because of the recent land use history in which the ecosystem has had no enough time to adjust consistently under livestock grazing disturbance. The observed positive correlation between SOC with TN and CEC implies the livestock grazing impacts on the former negatively affected the later soil parameters. The negative correlation between SOC and SAS regardless of the negative livestock grazing impacts means the aforementioned parameters respond independently under this disturbance. Low fungal density in degraded parts of the montane forest showed that livestock grazing affected the microbial habitat. The soil fungal communities of the montane forest have not been adapted to the aforementioned impacts and hence are sensitive to the current land use change, which is not compatible with natural biodiversity conservation objectives. Based on the observation from this study, it can be regarded that excessive livestock grazing decreases the soil quality in the impacted parts of the montane forest. This has a long-term negative ramification for biodiversity conservation in montane forest of Mount Kilimanjaro. An important decision has to be sought off with regard to the conservation management of soil characteristics of the montane forest in Kilimanjaro National Park.

\section{Acknowledgements}

The author is grateful of Mr. Imani Kikoti who worked hard in data collection in the field and Mr. Suleiman a botanical assistant who assisted in classification of habitat in the field based on different levels of grazing regimes.

\section{References}

[1] Hemp, A. (2001) Ecology of the Pteridophytes on the Southern Slopes of Mount Kilimanjaro. Part II: Habitat Selection. Plant Biology, 3, 493-523. http://dx.doi.org/10.1055/s-2001-17729

[2] Lambretchs, C., Woodley, B., Hemp, A., Hemp, C. and Nnyiti, P. (2002) Aerial Survey of the Threats to Mount Kilimanjaro Forests. UNDP, Dar es Salaam, 33 p.

[3] Watkinson, A.R. and Ormerod, S.J. (2001) Grasslands, Grazing and Biodiversity: Editors' Introduction. Journal of Applied Ecology, 38, 233-237. http://dx.doi.org/10.1046/j.1365-2664.2001.00621.x

[4] Jafarian, Z. and Kavian, A. (2013) Effects of Land-Use Change on Soil Organic Carbon and Nitrogen. Communi- 
cations in Soil Science and Plant Analysis, 44, 339-346. http://dx.doi.org/10.1080/00103624.2013.741949

[5] Kikoti, I.A. and Mligo, C. (2015) Impacts of Livestock Grazing on Plant Species Composition in Montane Forests on the Northern Slope of Mount Kilimanjaro, Tanzania. International Journal of Biodiversity Science, Ecosystem Services \& Management, 11, 114-127. http://dx.doi.org/10.1080/21513732.2015.1031179

[6] Kikoti, I.A., Mligo, C. and Benedicto, D. (2015) The Impact of Grazing on Plant Natural Regeneration in Northern Slopes of Mount Kilimanjaro, Tanzania Kilemo. Open Journal of Ecology, 5, 266-273.

http://dx.doi.org/10.4236/oje.2015.56021

[7] Roberson, E. (1996) Impacts of Livestock Grazing on Soils and Recommendations for Management. CNPS Land Management, $12 \mathrm{p}$.

[8] Ganjegunte, G.K., Vance, G.F., Preston, C.M., Schuman, G.E., Ingram L.J., Stahl, P.D. and Welker, J.M. (2005) Influence of Different Grazing Management Practices on Soil Organic Carbon Constituents in a Northern Mixed-Grass Prairie. Soil Science Society of America Journal, 69, 1746-1756. http://dx.doi.org/10.2136/sssaj2005.0020

[9] Piňeiro, G., Paruelo, J.M., Oesterheld, M. and Jobbágy, E.G. (2010) Pathways of Grazing Effects on Soil Organic Carbon and Nitrogen. Rangeland Ecology \& Management, 63, 109-119. http://dx.doi.org/10.2111/08-255.1

[10] Li, W., Huang, H., Zhang Z. and Wu, G. (2011) Effects of Grazing on the Soil Properties and C and N Storage in Relation to Biomass Allocation in an Alpine Meadow. Journal of Plant Nutrition and Soil Science, 11, 27-39.

[11] Allen, S.E., Ed. (1989) Chemical Analysis of Ecological Materials. 2nd Edition, Blackwell Scientific Publications, Oxford and London.

[12] Dlapa, P., Chrenkova, K., Hrabovsky, A., Mataix Solera, J., Kollar, J., Simkovic, I. and Jurani, B. (2011) The Effect of Land Use on Soil Aggregate Stability in the Viticulture District of Modra (SW Slovakia). Ekologia (Bratislava), 30, 397-404.

[13] Mataix-Solera, J., Cerda, A., Arcenegui, V., Jordan, A. and Zavala, I.M. (2011) Fire Effects on Soil Aggregation. A Review. Earth-Science Reviews, 109, 44-60. http://dx.doi.org/10.1016/j.earscirev.2011.08.002

[14] Diaz-Zorita, M., Perfect, E. and Grove, J.H. (2002) Disruptive Methods for Assessing Soil Structure. Soil \& Tillage Research, 64, 3-22. http://dx.doi.org/10.1016/S0167-1987(01)00254-9

[15] Six, J., Elliott, E.T. and Paustian, K. (2000) Soil Macro-Aggregate Turnover and Micro-Aggregate Formation: A Mechanism for C Sequestration under No-Tillage Agriculture. Soil Biology \& Biochemistry, 32, 2099-2103. http://dx.doi.org/10.1016/S0038-0717(00)00179-6

[16] Mwendera, E.J., Saleem, M.A.M. and Woldu, Z. (1997) Vegetation Response to Cattle Grazing in the Ethiopian Highlands. Agriculture, Ecosystems \& Environment, 64, 43-51. http://dx.doi.org/10.1016/S0167-8809(96)01128-0

[17] Scharlemann, J.P.W., Tanner, E.V.J., Hiederer, R. and Kapos, V. (2014) Global Soil Carbon: Understanding and Managing the Largest Terrestrial Carbon Pool. Carbon Management, 5, 81-91. http://dx.doi.org/10.4155/cmt.13.77

[18] TANAPA (2006) General Management Plan for Kilimanjaro National Park (2006-2015). Tanzania National Parks/ UNDP/CAWM.

[19] Hemp, A. (2005) Climate Change Driven Forest Fires Marginalizes the Ice Cap Wasting on Mount Kilimanjaro. Global Change Biology, 11, 1013-1023. http://dx.doi.org/10.1111/j.1365-2486.2005.00968.x

[20] Thompson, L.G., Mosley-Thompson, E., Davis, M.E., Henderson, K.A., Brecher, H.H., Zagorodnov, V.S., Mashiotta, T.A., Lin, P.N., Mikhalenko, V.N., Hardy, D.R. and Beer, J. (2002) Kilimanjaro Ice Core Records: Evidence of Holocene Climate Change in Tropical Africa. Science, 298, 589-593. http://dx.doi.org/10.1126/science.1073198

[21] Noe, C. (2003) The Dynamic of Land Use Changes and Their Impacts on Wildlife Corridor between Mt. Kilimanjaro and Amboseli National Park, Tanzania. Land Use Change, Impacts and Dynamics (LUCID) Project Working Paper No. 31, International Livestock Research Institute, Nairobi.

[22] Kikoti, I.A. (2013) The Impacts of Livestock Grazing on Vegetation in Montane Forest of the Northern Slopes of Mount Kilimanjaro. Unpublished Master's Thesis, University of Dar es salaam, Dar es Salaam.

[23] Warren, S.D., Nevill, M.B., Blackburn, W.H. and Garza, N.E. (1986) Soil Response to Trampling under Intensive Rotation Grazing. Soil Science Society of America Journal, 50, 1336-1341. http://dx.doi.org/10.2136/sssaj1986.03615995005000050050x

[24] Nelson, D.W. and Sommers, L.E. (1982) Total Carbon, Organic Carbon and Organic Matter. In: Page, A.L., Ed., Methods of Soil Analysis, Part 2, American Society of Agronomy and Soil Science Society of America, Madison, 539577.

[25] Stevenson, F.J. (1982) Nitrogen-Organic Forms. In: Page, A.L., Ed., Methods of Soil Analysis, Part 2, American Society of Agronomy and Soil Science Society of America, Madison, 625-641.

[26] Tolsma, D.J., Ernst, W.H.O. and Verweg, R.A. (1987) Seasonal Variation of Nutrient Concentrations in Semi-Arid Savanna Ecosystem in Botswana. Journal of Ecology, 75, 755-770. http://dx.doi.org/10.2307/2260204 
[27] Singh, M.J. and Khera, K.L. (2009) Physical Indicators of Soil Quality in Relation to Soil Erodibility under Different Land Uses. Arid Land Research and Management, 23, 152-167. http://dx.doi.org/10.1080/15324980902817147

[28] Graphpad Instat (2003) GraphpadInstat Software Inc, 3.06.

[29] Steel, R.G.D. and Torrie, J.H. (1980) Principles and Procedures of Statistics. 2nd Edition, McGraw-Hill, New York, $481 \mathrm{p}$.

[30] Vermeire, L.T., Wester, D.B., Mitchell, R.B. and Fuhlendorf, S.D. (2005) Fire and Grazing Effects on Wind Erosion, Soil Water Content, and Soil Temperature. Journal of Environmental Quality, 34, 1559-1565. http://dx.doi.org/10.2134/jeq2005.0006

[31] Frank, A.B., Tanaka, D.L., Hofmann, L. and Follett, R.F. (1995) Soil Carbon and Nitrogen of Northern Great Plains Grasslands as Influenced by Long-Term Grazing. Journal of Range Management, 48, 470-474. http://dx.doi.org/10.2307/4002255

[32] Reeder, J.D., Schuman, G.E., Morgan, J.A. and Lecain, D.R. (2004) Response of Organic and Inorganic Carbon and Nitrogen to Long-Term Grazing of the Short Grass Steppe. Environmental Management, 33, 485-495. http://dx.doi.org/10.1007/s00267-003-9106-5

[33] Liebig, M., Gross, J., Kronberg, S., Hanson, J., Frank, A. and Phillips, R. (2006) Soil Response to Long-Term Grazing in the Northern Great Plains of North America. Agriculture, Ecosystems \& Environment, 115, 270-276. http://dx.doi.org/10.1016/j.agee.2005.12.015

[34] Mligo, C. (2008) Determination of the Soil Organic Carbon, Total Nitrogen, Available Phosphorus and the Combined above Ground Plant Materials in the Semi-Arid Mbulu District, Tanzania. African Journal of Ecology, 47, 352-359.

[35] Butterworth, M.H. (1985) Beef Cattle Nutrition and Tropical Pastures. Longman, London.

[36] Wild, A. (1993) Soils and Environment: An Introduction. Cambridge University Press, Cambridge. http://dx.doi.org/10.1017/CBO9780511623530

[37] Muoghalu, J.I. and Awokunle, H.O. (1994) Spatial Patterns of Soil Properties under Tree Canopy in Nigeria Rain Forest Region. Journal of Tropical Ecology, 35, 219-228.

[38] Ingram, L.J., Schuman, G.E., Buyer, J.S., Vance, G.F., Ganjegunte, G.K., Welker, J.M. and Demer, J.D. (2008) Grazing Impacts on Soil Carbon and Microbial Communities in a Mixed Grass Ecosystem. Soil Science Society of America Journal, 72, 939-948. http://dx.doi.org/10.2136/sssaj2007.0038

[39] Heaney, A. and Proctor, J. (1989) Chemical Elements in Litter in Forests. In: Proctor, J., Ed., Mineral Nutrients in Tropical Forest and Savanna Ecosystems, British Ecological Society Special Publication, No.9, Blackwell Scientific Publications, Oxford, 255-271.

[40] Brady, N. and Weil, R.R. (1996) The Nature and Properties of the Soils. 13th Edition, Prentice-Hall, Inc., Upper Saddle River, 960.

[41] Mamolos, A.P., Veresolous, D.S. and Barbayiaunis, N. (1995) The Plant Species Abundance and Tissue Concentration of Limiting Nutrients in Low Nutrient Grasslands: A Test of Comparative Theory. Journal of Ecology, 83, 485-495. http://dx.doi.org/10.2307/2261601

[42] Biamas-George, M. (2012) Soil Nutrient Composition in Afromontane Forests of Northern Ethiopia. Colgate Academic Review, 8, 13.

[43] Berendse, F. (1998) Effects of Dominant Plant Species on Soil during Succession in Nutrient Poor Ecosystems. Biogeochemistry, 42, 73-88.

Tanja, A.J., Vander, K. and Berendse, F. (2001) The Effect of Plant Species on Soil Nitrogen Mineralisation. Journal of Ecology, 89, 555-561.

[44] Songwe, N.C., Okali, D.U.U. and Fasehun, F.E. (1995) Litter Decomposition and Nutrient Release: In a Tropical Rain Forest, Southern-Bakundu-Forest-Reserve, Cameroon. Journal of Tropical Ecology, 11, 333-350. http://dx.doi.org/10.1017/S0266467400008816

[45] Hatton, J.C. and Smart, N.O.E. (1984) The Effects of Long Term Exclusion of Large Herbivores on Soil Nutrient Status in Murchison Falls National Park, Uganda. African Journal of Ecology, 22, 23-30. http://dx.doi.org/10.1111/j.1365-2028.1984.tb00670.x

[46] Johnson, N.C., Hoeksema, J.D., Bever, J.D., et al. (2006) From Lilliput to Brobdingnag: Extending Models of Mycorrhizal Function across Scales. BioScience, 56, 889-900. http://dx.doi.org/10.1641/0006-3568(2006)56[889:FLTBEM]2.0.CO;2

[47] Gol, C. (2009) The Effect of Land Use Change on Soil Properties and Organic Carbon at Dagdami River Catchment in Turkey. Journal of Environmental Biology, 30, 825-830.

[48] Stewart, A. and Frank, D. (2008) Short Sampling Intervals Reveal Very Rapid Root Turnover in Temperate GrassLand. Oecologia, 157, 453-458. http://dx.doi.org/10.1007/s00442-008-1088-9 
[49] Taja, A.J., Vander, K. and Berendse, F. (2001) The Effect of Plant Species on Soil Nitrogen Mineralization. Journal of Ecology, 89, 555-561. http://dx.doi.org/10.1046/j.0022-0477.2001.00580.x

[50] Shrestha, B.M., Singh, B.R., Sitaula, B.K., Lal, R. and Bajracharya, R.M. (2007) Soil Aggregate and Particle-Associated Organic Carbon under Different Land Uses in Nepal. Soil Science Society of America Journal, 7, 1194-1203. http://dx.doi.org/10.2136/sssaj2006.0405

[51] Bronick, C.J. and Lal, R. (2005) Soil Structure and Management: A Review. Geoderma, 124, 3-22. http://dx.doi.org/10.1016/j.geoderma.2004.03.005

[52] Chacon, P., Lorenz, K., Lal, R., Calhoun, F.G. and Fausey, N. (2015) Soil Organic Carbon in Some Land Uses of Costa Rica. Acta Agriculturae Scandinavica, Section B-Soil \& Plant Science, 65, 310-320. http://dx.doi.org/10.1080/09064710.2015.1008563

[53] Hobley, E., Willgoose, G.R., Frisia, S. and Jacobsen, G. (2014) Vertical Distribution of Charcoal in a Sandy Soil: Evidence from DRIFT Spectra and Field Emission Scanning Electron Microscopy. European Journal of Soil Science, 65, 751-762. http://dx.doi.org/10.1111/ejss.12171

[54] Kageyama, S.A., Posavatz, N.R., Jones, S.S., Waterstripe, K.E., Bottomley, P.J., Cromack, K. and Myrold, D.D. (2013) Effects of Disturbance Scale on Soil Microbial Communities in the Western Cascades of Oregon. Plant Soil, 372, 459471. http://dx.doi.org/10.1007/s11104-013-1760-7

[55] Wedin, D.A. and Tilman, N. (1990) Species Effects on Nitrogen Cycling. A Test with Perennial Grasses. Oecologia, 84, 433-441. http://dx.doi.org/10.1007/BF00328157

[56] Young, I.M. and Ritz, K. (2005) The Habitat of Soil Microbes. In: Bardget, R.D., Usher, M.B. and Hopkins, D.W., Eds., Biological Diversity and Function in Soils, Cambridge University Press, Cambridge, 31-41. http://dx.doi.org/10.1017/CBO9780511541926.003

[57] Allison, S.D. and Martiny, J.B.H. (2008) Resistance, Resilience, and Redundancy in Microbial Communities. Proceedings of the National Academy of Sciences of the United States of America, 105, 11512-11519. http://dx.doi.org/10.1073/pnas.0801925105

[58] Kadeba, O. (1974) Nutrient Relationship in Some Forest Reserve Soils in Northern Nigeria. Research Paper 29 (Savanna, Series), Federal Department of Forest Research, Ibadan Nigeria.

[59] Mligo, C. (2004) Pasture Dynamics in the Semi-Arid Mbulu District, Tanzania. Unpublished Master's Thesis, University of Dar es salaam, Dar es Salaam, 204. 